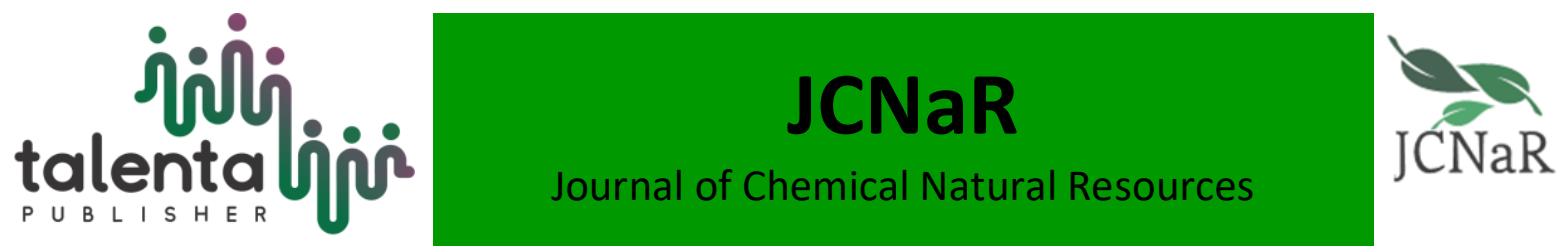

\title{
In Vitro Determination of SunProtective Factor (SPF) of Dadap Serep (Erythrina Subumbrans (Haks.) Merr.) Leaf Extract Using Spectrophotometric Method
}

\author{
Indri Maharini ${ }^{1 *}$, Diah Tri Utami ${ }^{2}$, Fitrianingsih ${ }^{3}$ \\ ${ }^{1,2,3}$ Department of Pharmacy, Faculty of Science and Technology, Universitas Jambi
}

\begin{abstract}
Dadap serep (Erythrina Subumbrans Haks Merr) contains bioactive compounds of flavonoids, saponins, isoflavones, alkaloids, and lectins. Flavonoid compounds have a sunscreen effect. This studyaimed to determinethe value of Sun Protective Factor (SPF) using spectrophotometry method with variations in the extract concentrations, such as500 ppm,750 ppm, and $1000 \mathrm{ppm}$. The results showed that the SPF values of each concentration were11.47 $\pm 0.583335,17.05 \pm 0.898838,21.93 \pm 0.791557$, respectively. In conclusion, the ethanol extract of dadap serep hastheability to become sunscreen in the maximal and ultra category.
\end{abstract}

Keyword:Dadap serep, SPF

Received November 1, 2018| Revised December 19, 2018 | Accepted January 19, 2019

\section{Introduction}

Sunlight is a source of energy which is beneficial to human life. However, sunlight also has harmful effects on the skin. For example, strong exposure tosunlight can cause erythema and sunburn (burning skin) whereas excessive and prolonged exposure might cause degeneration of the skin, such as premature aging and some skin cancers (Hadinoto et al.,2000). One way which can be done to reduce the negative effects of sunlight is by using sunscreen (Heckman \& Coups, 2011).

Sunscreen is cosmetic substances that can physically or chemically inhibit the penetration of UV light into the skin. Sunscreen can absorb at least $85 \%$ of the sunlight at a wavelength of 290-320 nm for UVB, it but can continue the light at wavelengths of more than $320 \mathrm{~nm}$ for UVA (Suryanto, 2012).

*Corresponding author at:Department of Pharmacy, Faculty of Science and Technology, Universitas Jambi, Jambi, Indonesia

E-mail address: indri.maharini@unja.ac.id 
The current development of sunscreen is more focused on the use of natural materials. Natural compounds that function as sunscreen are phenolic compounds. Phenolic compounds, especially flavonoids and tannins, have the sunscreen potentialbecause of the presence of chromophore groups (conjugated single double bonds) which can absorb UV light, both UV A and UV B (Shovyana et al., 2013).

Dadap serep (Erythrina subumbrans (Haks.) Merr.) isone of the plants that have the potential to be developed as sunscreen. This plant contains bioactive compounds of flavonoids, saponins, isoflavonoids, alkaloids, and lectins (Rukachaisirikulet al., 2007).

Therefore, this study aimed to investigate the potential of dadap serep leaf extract(Erythrina subumbrans (Haks.) Merr.) as a plant that has the effect of sunscreens by determining thein vitro SPF valueusing a spectrophotometric method.

\section{Materials And Method}

\subsection{Materials}

Materials used in this study were dadap serep leaves (Erythrina subumbrans (Haks.) Merr.),70\%ethanol, 96\%ethanol, and aquadest.Samples of dadap serep leaves were collected and washed thoroughly with running water. The leaves were then cut into a width of $1 \mathrm{~cm}$. The leaves were dried in an oven at a temperature of $40^{\circ} \mathrm{C}$, blended, and then sifted.

\subsection{Extraction}

Dadap serep leaf powder was dissolved with $70 \%$ ethanol and macerated for 24 hours. The sample was filtered and separated from the dregs and filtrates. The obtained ethanol filtrates werethen concentrated with a rotary evaporator $\left(40-50^{\circ} \mathrm{C}\right)$ so that the thick extract of dadap serep leaves was obtained.

\subsection{Determination of Sun Protective Factor (SPF) Values}

The determination of the SPF values was conducted in vitro with a UV-Vis spectrophotometer. The concentration variations of dadap serep leaf extract in determining the SPF values were 500 ppm, $750 \mathrm{ppm}$, and $1000 \mathrm{ppm}$. A total of $0.5 \mathrm{~g}$ of extract were dissolved using $25 \mathrm{ml}$ of $96 \%$ ethanol. Then, the solution was diluted until three variations of concentration were obtained. The obtained solutionwas measured by UV-Vis spectrophotometer at wavelengths of 290-320 nm using ethanol as a blank. The absorption values were recorded at every interval of 5 $\mathrm{nm}$ from the wavelengths of 290-320 $\mathrm{nm}$. The absorbance results were recorded, andthe SPF values were calculated using the following equation:

$$
\mathrm{SPF}=\mathrm{CF} \times \sum_{290}^{320} E E(\lambda) \times I(\lambda) \times \operatorname{abs}((\lambda)
$$

Where: 
$\mathrm{CF}=$ Correction Factor

$\mathrm{EE}=$ Erythemal effect spectrum

$\mathrm{I}=$ Solar intensity spectrum

Abs $=$ Absorbance of samples

\section{Results and Discussion}

One method to determine the activity of sunscreens is to measure the magnitude of the sun protection factor or known as SPF (Sun Protective Factor). SPF is defined as the amount of UV energy required to produce MED (Minimal Erythema Dose) on the skin which is protected by products or active substances of sunscreen divided by the amount of UV energy required to produce MED on the skin which is not protected by products or active sunscreen substances (Susanti et al., 2012).

The SPF values of dadap serep leaf ethanol extract were determined using a UV-Vis spectrophotometer at the wavelengths of UV B sunlight (290-320 nm). According to the FDA (Food and Drug Administration), the classification of the sunscreen ability is divided into 5 categories: Minimal, Medium, Extra, Maximum, and Ultra (Damogalad, 2013).

Table 1 The classification of sunscreen ability according to the FDA

\begin{tabular}{cc}
\hline Ability & SPF Values \\
\hline Minimal & $2-4$ \\
Medium & $4-6$ \\
Extra & $6-8$ \\
Maximal & $8-15$ \\
Ultra & More than 15
\end{tabular}

Based on the results of the SPF valuesdetermination shown in Table 2, the concentration of 500 ppm, $750 \mathrm{ppm}$, and $1000 \mathrm{ppm}$ of dadap leaf extract had the ability as sunscreen in the maximum and ultra category. Phenolic and flavonoid compounds contained in dadap serep leaf extract has the potential to become sunscreen because it contains chromophore groups. This structure absorbs high-energy ultraviolet light and releases the energy in the form of low-energy light which prevents ultraviolet light that causes damage to the skin (Shantanu et al., 2011). 
Table 2 The Results of SPF Values Determination of Dadap Serep Ethanol Extract

\begin{tabular}{cc}
\hline Concentration & SPF Value \\
\hline $500 \mathrm{ppm}$ & $11.47 \pm 0.583335$ \\
$750 \mathrm{ppm}$ & $17.05 \pm 0.898838$ \\
$1000 \mathrm{ppm}$ & $21.93 \pm 0.791557$ \\
\hline
\end{tabular}

\section{Conclusion}

The concentration variations of $500 \mathrm{ppm}, 750 \mathrm{ppm}$, and $1000 \mathrm{ppm}$ of dadap leaf extract had the ability of sunscreen in the maximum and ultra category. Dadap serep leaf extract(Erythrina subumbrans (Haks.) Merr.) has the potential to be developed into sunscreen preparations to be more easily applied.

\section{Acknowledgment}

The authors would like to acknowledge the Faculty of Science and Technology in Jambi University which have provided the facility to support the implementation of this research.

\section{References}

Damogalad, V., Edy, H. J. and Supriati, H. S., 2013, Formulasi Krim Tabir Surya Ekstrak Kulit Nanas (Ananas comosus L. Merr) dan Uji In Vitro Nilai Sun Protecting Factor (SPF), Pharmacon J. Ilmiah Farmasi Unsrat, Vol. 2, pp. 39-43.

Hadinoto, I..S.W..d.M.C.T., 2000, Pengaruh pH terhadap Efektivitas Sediaan Tabir Matahari dengan Bahan Aktif Heksil p Metoksianamat dan Oksilbenzen dalam Basis Hidrofilik Krim Secara In Vitro, In Kongres Ilmiah XIII IKatan Sarjana Farmasi Indonesia, Jakarta.

Heckman, C.J. and Coups, E.J. 2011, Correlates of Sunscreen Use Among High School Students: a Cross Sectional Survey, BMC Public Health, Vol. 11(679), pp. 1-7.

Rukachaisirikul, T., Innok, P., Aroonrerk, N., Boonamnuaylap, W., Limrangsun, S., Boonanyon, C., Woonjina, U., and Suksamrarn, A., 2007, Antibacterial Pterocarpans From Erythrina subumbans, J. Ethnophamacol,Vol. 110, pp.171-175.

Shantanu, S.K., Rajmane, A. H., Urunkar, V. C., Gaikward, M.K., and Bhandare, S. B., 2011, Formulation And In-Vitro Evaluation Of Sun Protection Factor Of Methanolic Extract Of Zanthoxylum rhetsa DC. Sunscreen lotion,Research Journal Pharmacognosy and phytochemistry, Vol. 3(5), pp. 206-210.

Shovyana, H.H., and A. Karim Zulkarnain, 2013, Physical Stability and Activity of Cream W/O Etanolic Fruit Extract of Mahkota Dewa (Phaleria macrocarpha (scheff.) Boerl,) as A a Sunscreen,Traditional Medicine Journal,Vol. 18(2).

Suryanto E., 2012,Fitokimia Antioksidan. Putra Media Nusantara, Surabaya.

Susanti, M., Dachriyanus, and Doni Permana Putra, 2012, Aktivitas Perlindungan Sinar UV Kulit Buah Garcinia mangostana Linn SecaraIn Vitro,Pharmacon J. Ilmiah Farmasi Unsrat, Vol. 13(2), pp. 61-64. 